\title{
Chemical migration during soil water retention curve evaluation
}

\author{
LUIZ F. PIRES ${ }^{1}$, FELIPE C.A. VILLANUEVA ${ }^{2}$, NIVEA M.P. DIAS ${ }^{1,3}$, \\ OSNY O. SANTOS BACCHI ${ }^{2}$ and KLAUS REICHARDT ${ }^{2}$ \\ ${ }^{1}$ Laboratório de Física Aplicada a Solos e Ciências Ambientais, Universidade Estadual de Ponta Grossa/UEPG, \\ Av. Gen. Carlos Cavalcanti, 4748, 84030-900 Ponta Grossa, PR, Brasil \\ ${ }^{2}$ Centro de Energia Nuclear na Agricultura, USP/CENA, Caixa Postal 96, 13400-970 Piracicaba, SP, Brasil \\ ${ }^{3}$ Departamento de Ciência do Solo, Universidade Estadual de Ponta Grossa/UEPG, \\ Av. Gen. Carlos Cavalcanti, 4748, 84030-900 Ponta Grossa, PR, Brasil
}

Manuscript received on August 11, 2009; accepted for publication on December 29, 2010

\begin{abstract}
Wetting and drying (W-D) cycles can induce important elemental migrations in soils. The main purpose of this work was to study the possible existence of soil chemical elemental migrations in samples submitted to repeated W-D cycles during evaluations of soil water retention curve (SWRC). The experimental measurements were carried out by Atomic Absorption Spectrometry (AAS) for $\mathrm{Ca}^{2+}, \mathrm{Mg}^{2+}$ and $\mathrm{K}^{+}$on samples of three different Brazilian tropical soils (Geric Ferralsol, Eutric Nitosol and Rhodic Ferralsol). Results demonstrate an increase in the electrical conductivity of the water extracted from the samples and significant losses of $\mathrm{Ca}^{2+}, \mathrm{Mg}^{2+}$ and $\mathrm{K}^{+}$during the applications of up to nine W-D cycles. It was also observed differences in SWRC for all soils when samples submitted to the application of several W-D cycles were compared with samples not submitted to it. These differences occurred at the region of both structural and textural pores. A possible explanation for these results could be the soil chemical migration during the sequences of W-D cycles, which can affect the soil structure development.
\end{abstract}

Key words: analytical methods, soil structure, wetting-drying cycles, soil physics.

\section{INTRODUCTION}

The relationship between soil water matric potential $(\Psi \mathrm{m})$ and the respective water content $(\theta)$, identified as the soil water retention curve (SWRC), represents a fundamental part of the soil hydraulic and physical characterization (Richards 1941). The SWRC is used to predict the retention of water available to plants and water movement through the soil. This hydraulic property is several times taken as a static characteristic of a given soil (Klute 1986). During its evaluation, the most common methodology submits a same soil sample to a series of wetting and drying (W-D) cycles that can cause important changes in soil structure, especially in pore size distribution, with practical consequences when cal-

Correspondence to: Luiz Fernando Pires

E-mail: 1fpires@uepg.br; luizfpires@gmail.com culating $\theta$ storages and $\Psi \mathrm{m}$ values widely used in the irrigation management. When these changes occur, the SWRC cannot be considered a static soil property.

As the soil water matric potential is less than zero (negative) for high values of $\Psi \mathrm{m}$ near soil saturation, the SWRC depends very much on soil structure or particle-size distribution, and for low values of $\Psi \mathrm{m}$ (very negative), which appear as the soil becomes drier, it is related to soil texture and less to the arrangement of the particles (Salter and Williams 1965, Reeve et al. 1973). When the procedure to measure the SWRC involves repeated W-D cycles on the same soil sample, possible chemical elements migration can occur as a consequence of these cycles. This migration can lead to important changes in the content of some chemical elements of the soil, e.g. $\mathrm{Ca}^{2+}, \mathrm{K}^{+}$and $\mathrm{Mg}^{2+}$, and influence the water retention mainly at the region of low $\Psi \mathrm{m}$. 
According to some scientific reports (Russo and Bresler 1977, Frenkel et al. 1978, Oliveira et al. 2005), water retention and movement can present differences due to 1) increases in the $\mathrm{Na}$ to $\mathrm{Ca}$ ratio of soil samples saturated with solutions containing these ions in their composition; 2) changes in water-dispersible clay as a result of modifications in the distribution of chemical elements inside the soil; and 3 ) alterations in soil porosity by dispersed clay particles caused by changes in the ion concentration of soils. In spite of these facts, no systematic studies on possible soil chemical element migrations during the SWRC evaluations were published in the soil science literature for tropical soils.

The purpose of this investigation was twofold: first, to design a practical method to measure chemical elements in the soil solution flow (migration) during the SWRC evaluation; and second, to analyze possible changes of soil ion composition after W-D cycles and their impacts on water retention. Such information is valuable to understand the physical, chemical and physicochemical processes that occur in soil samples submitted to W-D cycles during the measurement of soil hydraulic properties in the laboratory, as well as in natural soils in the field.

\section{MATERIALS AND METHODS}

Soll SAMPLING AND Wetting AND DRYING (W-D) OF SAMPLES

Core samples were collected in Piracicaba, SP, Brazil $\left(22^{\circ} 4^{\prime} \mathrm{S} ; 47^{\circ} 38^{\prime} \mathrm{W} ; 580 \mathrm{~m}\right.$ above sea level) and characterized as: Geric Ferralsol (GF) (770 sand, 50 silt, 180 clay, $16.0 \mathrm{~g} \mathrm{~kg}^{-1}$ organic matter (OM), $1.56 \mathrm{~g} \mathrm{~cm}^{-3}$ dry bulk density $\left(\mathrm{d}_{\mathrm{b}}\right)$, cations exchange $(\mathrm{CE}) 35.5 \mathrm{mmol}_{\mathrm{c}}$ $\mathrm{dm}^{-3} \mathrm{Ca}, 20.8 \mathrm{mmol}_{\mathrm{c}} \mathrm{dm}^{-3} \mathrm{Mg}, 2.6 \mathrm{mmol}_{\mathrm{c}} \mathrm{dm}^{-3} \mathrm{~K}$ ), Eutric Nitosol (EN) (240 sand, 330 silt, 430 clay, $20.2 \mathrm{~g} . \mathrm{kg}^{-1} \mathrm{OM}, 1.62 \mathrm{~g} \mathrm{~cm}^{-3} \mathrm{~d}_{\mathrm{b}}$, CE $24.6 \mathrm{mmol}_{\mathrm{c}} \mathrm{dm}^{-3}$ $\mathrm{Ca}, 14.5 \mathrm{mmol}_{\mathrm{c}} \mathrm{dm}^{-3} \mathrm{Mg}, 2.3 \mathrm{mmol}_{\mathrm{c}} \mathrm{dm}^{-3} \mathrm{~K}$ ) and Rhodic Ferralsol (RF) (150 sand, 290 silt, 560 clay, $27.0 \mathrm{~g} \mathrm{~kg}^{-1} \mathrm{OM}, 1.33 \mathrm{~g} \mathrm{~cm}^{-3} \mathrm{~d}_{\mathrm{b}}$, CE $8.4 \mathrm{mmol}_{\mathrm{c}} \mathrm{dm}^{-3}$ $\mathrm{Ca}, 5.9 \mathrm{mmol}_{\mathrm{c}} \mathrm{dm}^{-3} \mathrm{Mg}, 2.5 \mathrm{mmol}_{\mathrm{c}} \mathrm{dm}^{-3} \mathrm{~K}$ ), according to FAO classification (FAO 1998). The main soil chemical and physical properties were analyzed according to standard analytical methods recommended by Camargo et al. (1986) and van Raij et al. (1987).
Samples of GF were collected in a non-cultivated area, covered by grasses and weeds, near an Eucalyptus artificial forest; those of EN in a coffee field established in 2001; and those of RF in a native mixed forest. A total of twenty-four core samples $(3.0 \mathrm{~cm}$ high and $4.8 \mathrm{~cm}$ in diameter), eight from each soil, were collected from the soil surface layer $(3-7 \mathrm{~cm})$ from an area of approximately $1 \mathrm{~m}^{2}$ with aluminum cylinders using a stainless steel core sampler $(3.2 \mathrm{~cm}$ high and $5.0 \mathrm{~cm}$ internal diameter to allow the introduction of the aluminum cylinder).

Soil samples were wetted (W) to saturation by the capillary rise method. After the equilibrium of the capillary rise, samples were soaked in a tray with the water level just below the top of the aluminum rings for forty-eight hours, and assumed to be sufficient to saturate the samples and to minimize entrapped air bubbles (Klute 1986). Afterwards samples were partially dried (D) by submitting them to a $400 \mathrm{kPa}$ pressure $(\mathrm{P})$ in a pressure chamber. Repeating these procedures, samples were submitted to series of W-D cycles. For the evaluation of the SWRC, the procedures described in Klute (1986) were used. The Retention Curve software RETC (van Genuchten et al. 1991) was used to fit mean $\theta$ and $\Psi \mathrm{m}$ data for each soil and treatment.

\section{EXPERIMENTAL SeTUP FOR ATOMIC AbSORPTION SPECTROMETRY AND ElECTRICAL CONDUCTIVITY ANALYSES}

The Electrical Conductivity (EC) and the Atomic Absorption Spectrometry (AAS) analyses were carried out in the water used to saturate: 1) the ceramic porous plates; 2) the soil samples used for the determination of the SWRC; and 3) the water extracted from the samples in the pressure chamber (Fig. 1). The hydraulic contact between the water of the soil sample and the water at the reference potential is made through a porous plate or membrane. So, the main role of the ceramic porous plate is to produce an extension of the soil up to the bottom of the plate continuously submitted to the atmospheric pressure (reference potential). With constant pressure applications on the chamber, soil samples lost water through the plate until the equilibrium is reached. Details about the experimental procedure for the SWRC determination can be found in Klute (1986). Three samples of each soil yielded sufficient volume of 
extracted solution during each $\mathrm{D}$ procedure performed at $400 \mathrm{kPa}$ of pressure. A series of $9 \mathrm{~W}-\mathrm{D}$ cycles was used to perform the migration studies. One ceramic porous plate was used for each set of three samples of the same soil, and each set of soil samples and porous plates was saturated in a same water reservoir.

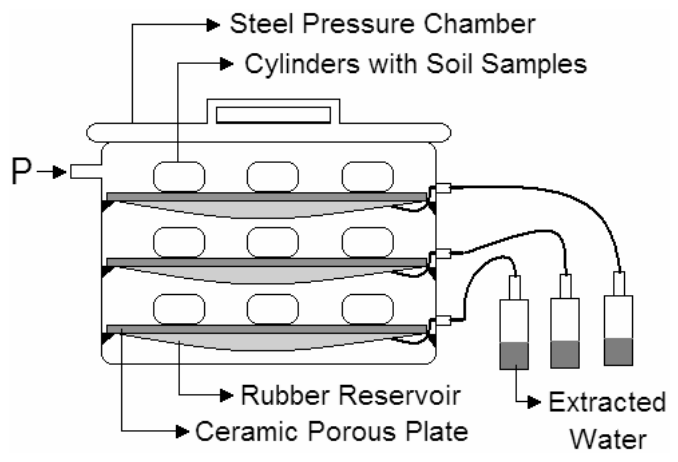

Fig. 1 - Experimental set-up designed to collect the extracted water from the pressure chambers used for the SWRC evaluation.

Water analysis before each sample wetting was carried out to check any variation in the water chemical composition during the application of the $9 \mathrm{~W}-\mathrm{D}$ cycles, being aware of the existence of any possible migration of a chemical element caused by water application. Water electrical conductivity analysis was performed at $25 \pm 1{ }^{\circ} \mathrm{C}$ with a conductivimeter, model CA-150, equipped with a platinum cell and temperature sensor with $1 \%$ of uncertainty. For the system calibration, a standard solution of conductivity $0.147 \mathrm{dS} \mathrm{m}^{-1}$ was used. AAS analyses of $\mathrm{Ca}^{2+}, \mathrm{Mg}^{2+}$ and $\mathrm{K}^{+}$were made using an atomic absorption spectrometer, model SpectrAA100.

AAS is an analytical technique for measuring elemental concentrations based on the specific absorption wavelength by atoms of different elements in an atomized sample - i.e., the measurement of state free atoms converted into the ground state in the vapor state. The amount of light absorbed is proportional to the number of specific atom species. With the help of a calibration curve, it is possible to calculate the concentration of the respective elements in the atomized sample.

\section{Statistical AND DATA ANALYsis}

Normality tests were performed on data prior to their statistical processing. An analysis of variance (ANOVA) and the Tukey multiple range test $(\mathrm{P}<0.05)$ were per- formed to analyze statistical differences and to discriminate means.

Relative differences $(\Delta \mathrm{C})$ between treatments (W-D cycles) were obtained by using the following equation:

$$
\Delta \mathrm{C}=\left|\frac{\mathrm{C}_{1}-\mathrm{C}_{9}}{\mathrm{C}_{1}}\right| \cdot 100
$$

where $\mathrm{C}_{1}$ and $\mathrm{C}_{9}$ represent samples submitted to 1 and $9 \mathrm{~W}-\mathrm{D}$ cycles, respectively. However, $\mathrm{C}_{1}$ is given by the difference between the faucet water used for the first wetting of samples and the water extracted after the first pressure application and, consequently, $\mathrm{C}_{9}$ is given by the difference between the faucet water used for the nine wetting and the water extracted after the nine pressure application.

\section{RESULTS AND DISCUSSION}

Electrical Conductivity analyses of the water used for the wetting of the samples practically remained constant for each W-D cycle (Table I). This result becomes evident when analyzing the angular coefficient of the adjustment straight line $(y=0.0006 x+0.1903)$. By analyzing Table $\mathrm{I}$ it is also possible to observe that there are no significant statistical differences (Tukey's multiple range test, $\mathrm{P}<0.05$ ) among the water used for the wetting of the samples for each W-D cycle.

In relation to the extracted water from soil samples (Fig. 2), all of them presented increases of EC giving an indication of chemical element migration from soils after replications of $\mathrm{W}-\mathrm{D}$ cycles. The results presented in Figure 2 represent the EC differences between wetting and extraction waters, using the wetting water as background. The greatest EC increases of the water extracted of soils occurred for the GF (Fig. 2a) and RF (Fig. 2c) soils, followed by the EN (Fig. 2b) one. It is possible to infer from these results that the GF and RF soils presented the greatest migration of chemical elements due to $\mathrm{W}-\mathrm{D}$ cycles. The relative differences $(\Delta \mathrm{C})$ of EC between the first $\left(\mathrm{C}_{1}\right)$ and last $\left(\mathrm{C}_{9}\right)$ W-D cycle for the three soils were: $145 \%(\mathrm{GF}), 58 \%(\mathrm{EN})$ and $105 \%$ (RF). The significant angular coefficients of the adjustment straight lines $(\mathrm{P}<0.05)$ show that all soils presented significant changes in EC after repeated $\mathrm{W}$ $\mathrm{D}$ cycles giving a clear indication of a strong migration of soil chemical elements following each W-D cycle. 
TABLE I

Data of EC ( $\left.\mathrm{dS} \mathrm{m}^{-1}\right), \mathrm{Ca}^{2+}, \mathrm{Mg}^{2+}$ and $\mathrm{K}^{+}$ concentrations $\left(\mathrm{mg} \mathrm{L}^{-1}\right)$ of the water used for wetting the soil samples.

\begin{tabular}{c|c|c|c|c}
\hline $\begin{array}{c}\mathrm{W}-\mathrm{D} \\
\text { cycles }^{\mathrm{A}}\end{array}$ & $\begin{array}{c}\mathrm{EC} \\
\left(\mathrm{dS} \mathrm{m}^{-1}\right)\end{array}$ & $\begin{array}{c}\mathrm{Ca}^{2+} \\
\left(\mathrm{mg} \mathrm{L}^{-1}\right)\end{array}$ & $\begin{array}{c}\mathrm{Mg}^{2+} \\
\left(\mathrm{mg} \mathrm{L}^{-1}\right)\end{array}$ & $\begin{array}{c}\mathrm{K}^{+} \\
\left(\mathrm{mg} \mathrm{L}^{-1}\right)\end{array}$ \\
\hline 1 & $0.187^{\mathrm{a}}$ & $0.47^{\mathrm{a}}$ & $0.044^{\mathrm{a}}$ & $32.2^{\mathrm{a}}$ \\
2 & $0.197^{\mathrm{a}}$ & $0.45^{\mathrm{ab}}$ & $0.044^{\mathrm{a}}$ & $32.3^{\mathrm{a}}$ \\
3 & $0.198^{\mathrm{a}}$ & $0.44^{\mathrm{ab}}$ & $0.043^{\mathrm{a}}$ & $32.2^{\mathrm{a}}$ \\
4 & $0.192^{\mathrm{a}}$ & $0.42^{\mathrm{bc}}$ & $0.042^{\mathrm{a}}$ & $31.5^{\mathrm{a}}$ \\
5 & $0.188^{\mathrm{a}}$ & $0.43^{\mathrm{bc}}$ & $0.042^{\mathrm{a}}$ & $31.0^{\mathrm{a}}$ \\
6 & $0.185^{\mathrm{a}}$ & $0.41^{\mathrm{c}}$ & $0.045^{\mathrm{a}}$ & $32.1^{\mathrm{a}}$ \\
7 & $0.194^{\mathrm{a}}$ & $0.42^{\mathrm{bc}}$ & $0.045^{\mathrm{a}}$ & $31.4^{\mathrm{a}}$ \\
8 & $0.197^{\mathrm{a}}$ & $0.41^{\mathrm{c}}$ & $0.044^{\mathrm{a}}$ & $32.3^{\mathrm{a}}$ \\
9 & $0.200^{\mathrm{a}}$ & $0.40^{\mathrm{c}}$ & $0.043^{\mathrm{a}}$ & $31.6^{\mathrm{a}}$ \\
\hline
\end{tabular}

${ }^{A}$ Faucet water was used for each wetting and drying (W-D) cycle; $\mathrm{EC}, \mathrm{Ca}^{2+}, \mathrm{Mg}^{2+}$ and $\mathrm{K}^{+}$mean values followed by the same letters (in columns among different W-D cycles) are not statistically different $(\mathrm{P}<0.05)$, as determined by the Tukey's multiple range test (completely randomized design, $\mathrm{n}=3$ ).

In order to refine the understanding of the results of $\mathrm{EC}$, the analysis of the concentrations of $\mathrm{Ca}^{2+}$, $\mathrm{Mg}^{2+}$ and $\mathrm{K}^{+}$made by AAS (Figs. 3 to 5 ) indicates concentration differences between wetting and extraction waters. Some statistical differences $(\mathrm{P}<0.05)$ were found only for $\mathrm{Ca}^{2+}$ (Table I) in the faucet water used for wetting the soil samples. These statistical differences for $\mathrm{Ca}^{2+}$ can be attributed to the use of calcium carbonate by the water treatment plant to correct the $\mathrm{pH}$ level of the faucet water. Usually, the rate of usage of the calcium carbonate is dependent on the $\mathrm{pH}$ of the water and the amount of treated water. This analysis was chosen because these three cations, together with $\mathrm{NO}_{3}^{-}, \mathrm{SO}_{4}^{2-}, \mathrm{Cl}^{-}$and $\mathrm{Na}^{+}$, are the most susceptible ions to be leached through soil profiles, and they represent the main share in soil nutrient losses, causing also soil acidification due to ion leaching (van Raij 1986, Sparks 1998, Havlin et al. 2005).

The relative difference $(\Delta \mathrm{C})$ of the $\mathrm{Ca}^{2+}$ (Fig. 3) concentration in the extraction water between $\mathrm{C}_{1}$ and $\mathrm{C}_{9} \mathrm{~W}-\mathrm{D}$ cycles for the GF soil was $436 \%$, while these differences for $\mathrm{Mg}^{2+}$ (Fig. 3) and $\mathrm{K}^{1+}$ (Fig. 3) were only $19 \%$ and $55 \%$, respectively. For the EN and RF soils (Figs. 4 and 5), the increase of $\mathrm{Ca}^{2+}, \mathrm{Mg}^{2+}$ and
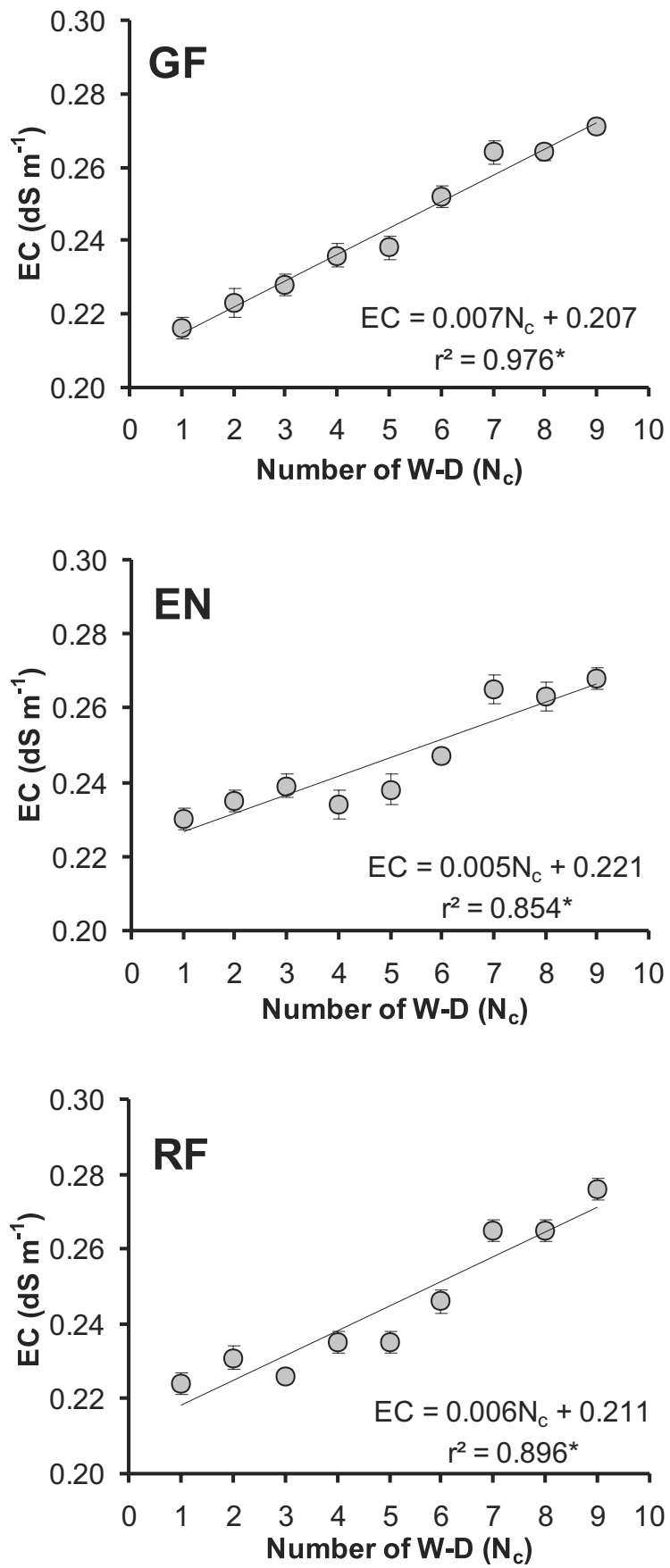

Fig. 2 - EC $\left(\mathrm{dS} \mathrm{m}^{-1}\right)$ variation of the extracted water after the application of W-D cycles for the three Brazilian soils (GF, EN and RF). *Significant to $5 \%$ by the $\mathrm{F}$ test.

$\mathrm{K}^{+}$concentrations of the extraction water was similar to that (increase) obtained for the GF soil. In relation to the EN soil (Fig. 4), $\Delta \mathrm{C}$ between $\mathrm{C}_{1}$ and $\mathrm{C}_{9}$ W-D cycles were $163 \%\left(\mathrm{Ca}^{2+}\right), 5 \%\left(\mathrm{Mg}^{2+}\right)$ and $38 \%\left(\mathrm{~K}^{+}\right)$. For the RF soil (Fig. 5), these relative differences were 

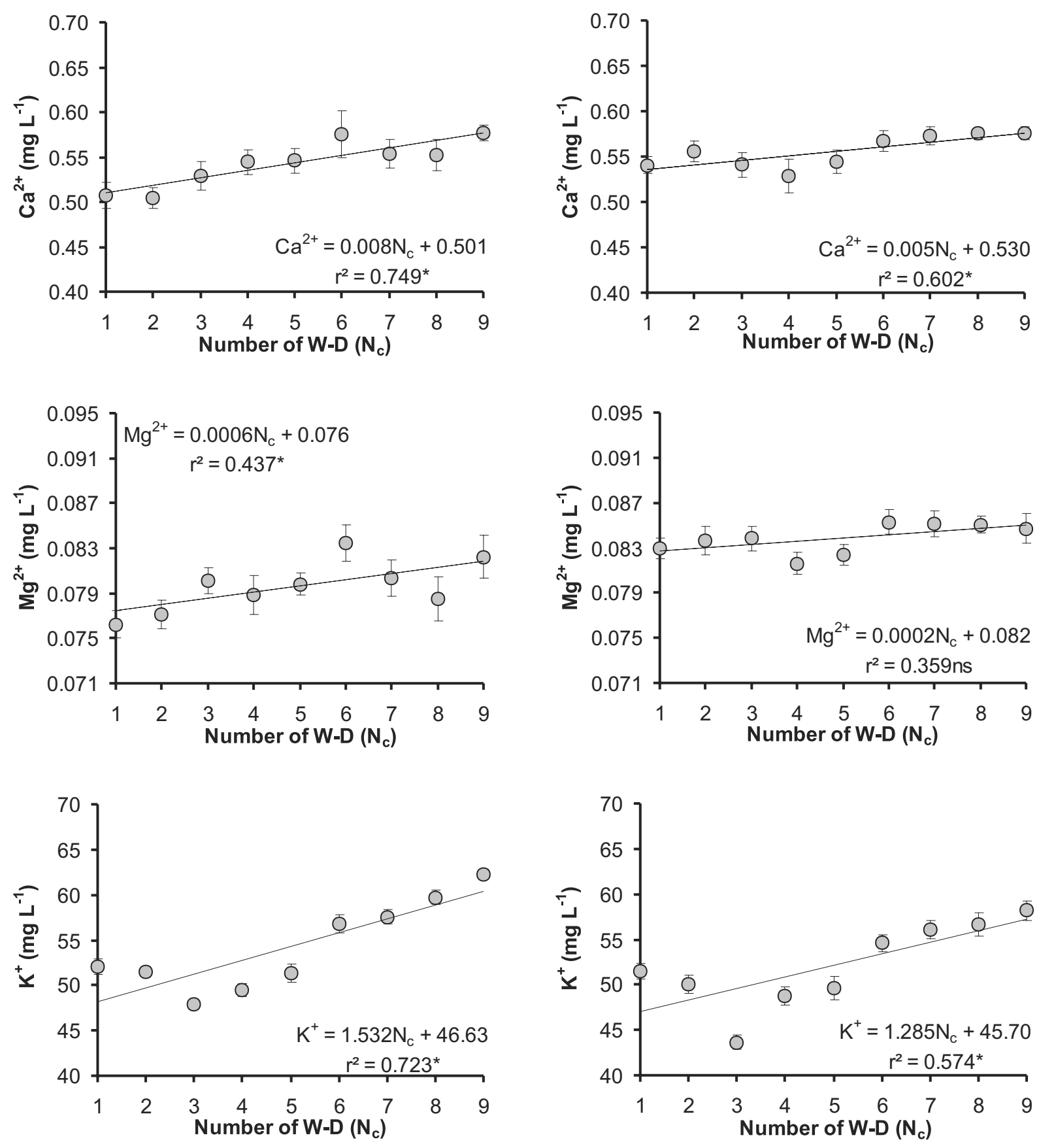

Fig. 3 - Calcium $\left(\mathrm{Ca}^{2+}\right)$, Magnesium $\left(\mathrm{Mg}^{2+}\right)$ and Potassium $\left(\mathrm{K}^{+}\right)$ variation of the extracted water after the application of W-D cycles for the GF soil. *Significant to $5 \%$ by the $\mathrm{F}$ test.

Fig. $4-\mathrm{Ca}^{2+}, \mathrm{Mg}^{2+}$ and $\mathrm{K}^{+}$variation of the extracted water after the application of W-D cycles for the EN soil. *Significant to $5 \%$ by the $\mathrm{F}$ test.

$248 \%\left(\mathrm{Ca}^{2+}\right), 16 \%\left(\mathrm{Mg}^{2+}\right)$ and $45 \%\left(\mathrm{~K}^{+}\right)$. According to the regression analysis, all soils presented statistical differences $(\mathrm{P}<0.05)$ of $\mathrm{Ca}^{2+}, \mathrm{Mg}^{2+}$ and $\mathrm{K}^{+}$losses with the application of W-D cycles, with the exception to the $\mathrm{Mg}^{2+}$ migration for the EN soil.

The results of $\Delta \mathrm{C}$ in ion concentrations between $\mathrm{C}_{1}$ and $\mathrm{C}_{9}$ W-D cycles show that $\mathrm{Ca}^{2+}$ was the most removed ion from the soil samples, followed by $\mathrm{K}^{+}$ and $\mathrm{Mg}^{2+}$. These results are in part in accordance with the lyotropic series that defines the strength of bonding 
between ions and clay surfaces (van Raij and Kupper 1966, van Raij 1969). This series is most commonly described in the order: $\mathrm{Ca}^{2+}>\mathrm{Mg}^{2+}>\mathrm{K}^{+}$and, therefore, for equivalent amounts of exchangeable cations the soil losses of $\mathrm{K}^{+}$are more significant than those of $\mathrm{Mg}^{2+}$ and $\mathrm{Ca}^{2+}$ (van Raij 1986). In this case, maybe the $\mathrm{Ca}^{2+}$ was the most removed ion from the soil samples because it was present in higher amount as an exchange cation than $\mathrm{Mg}^{2+}$ and $\mathrm{K}^{+}$, and the $\mathrm{Ca}^{2+}$ adsorbed to soil colloids tends to equilibrate with the $\mathrm{Ca}^{2+}$ of the soil solution. On the other hand, by the mass effect of the $\mathrm{K}^{+}$ ion, it was in a higher concentration in the faucet water used for wetting the soil samples (Table I).

The greatest $\Delta \mathrm{C}$ in ion concentrations between $\mathrm{C}_{1}$ and $\mathrm{C}_{9} \mathrm{~W}-\mathrm{D}$ cycles for these three ions occurred in the following soil sequence: $\Delta \mathrm{C}_{\mathrm{GF}}>\Delta \mathrm{C}_{\mathrm{RF}}>\Delta \mathrm{C}_{\mathrm{EN}}$. These results are in line with the relative differences for $\mathrm{EC}$ values of the three soils: $\mathrm{EC}_{\mathrm{GF}}>\mathrm{EC}_{\mathrm{RF}}>\mathrm{EC}_{\mathrm{EN}}$. According to van Raij (1986), the total lixing of cations depends on the anions present in the soil and, therefore, the $\mathrm{Ca}^{2+}$ losses should be related to the amounts of $\mathrm{K}^{+}$ and $\mathrm{Mg}^{2+}$ in the soil and to $\mathrm{K}^{+}$in the water used to wet soil samples.

In Figure 6, it is possible to observe the effect of the W-D cycles in samples of the three soils. The parameters, based on the van Genuchten equation with the Mualem restriction (Klute 1986) used for the mathematical adjustment of the SWRC, are presented in Table II.

From Figure 6, after the application of 0 and 9 W-D cycles, a higher amount of water remained in the soil samples for all applied matric potentials, excepting the EN soil. The EN and RF soils (Fig. 6) presented a similar behavior, with an increase in the difference of water retention for intermediate $\Psi \mathrm{m}$ and an approximation of the SWRC for lower $\Psi \mathrm{m}$ values (Fig. 7) On the other hand, the GF soil (Fig. 6) showed the opposite, with a constant increase in water retention for lower matric potentials (Fig. 7). This result is important due to its application in practical agriculture, once this additional water retained in the pores after W-D cycles can be used by plants and roots in the case of the GF and RF soils.

It is known that aggregated soils present differences between textural and structural pores (Kutílek 2004). Textural pores are basically related to the dis-
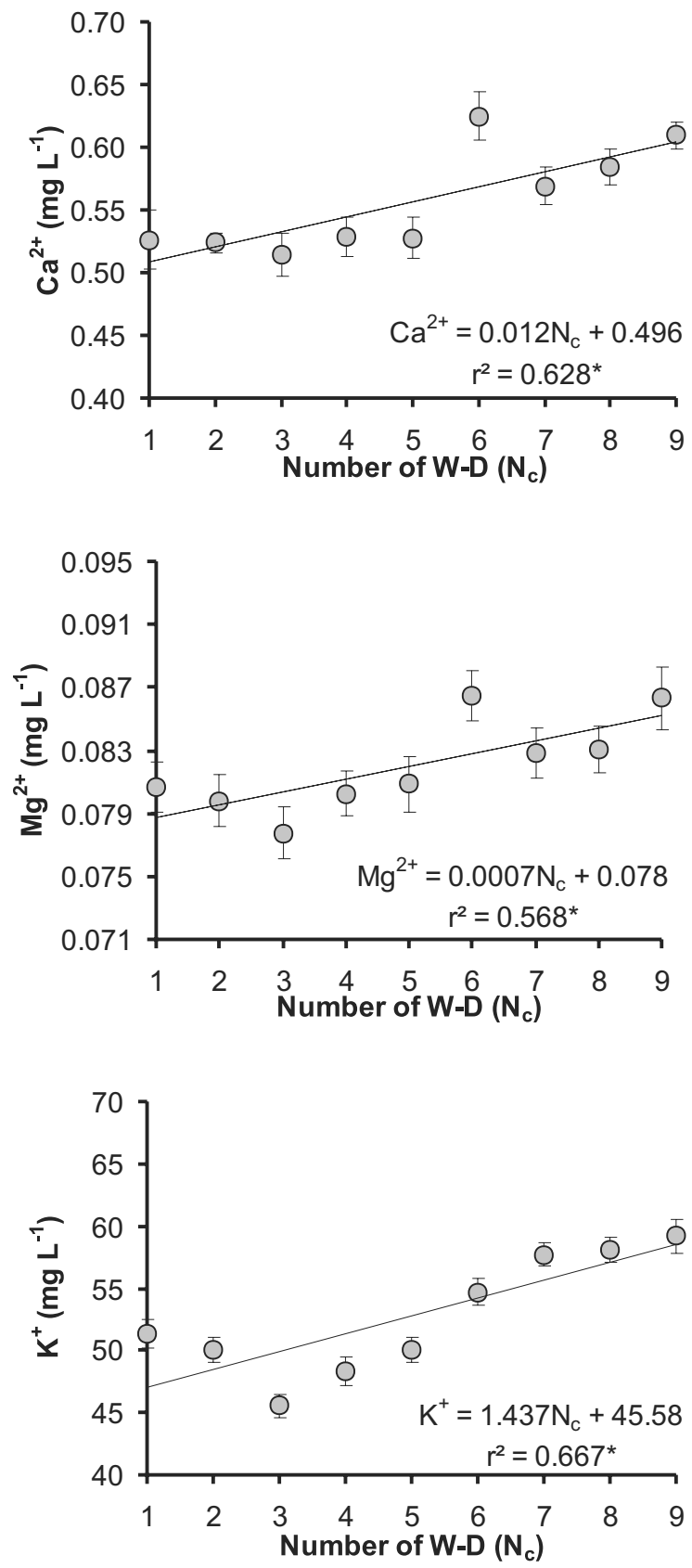

Fig. $5-\mathrm{Ca}^{2+}, \mathrm{Mg}^{2+}$ and $\mathrm{K}^{+}$variation of the extracted water after the application of W-D cycles for the RF soil. * Significant to $5 \%$ by the F test.

tribution of primary soil particles (sand, silt and clay), and structural ones are associated with shape, orientation and position arrangement of soil aggregates (Nimmo 1997). Textural pores are relatively more stable than structural pores, these last ones being more affected by natural soil processes or human actions. Sarmah et al. 
TABLE II

The SWRC parameters obtained for the van Genuchten equation for the soils submitted to $0 \mathrm{~W}$-D and $9 \mathrm{~W}$-D cycles.

\begin{tabular}{c|c|c|c|c|c|c}
\hline \multirow{2}{*}{ Parameters } & \multicolumn{2}{|c|}{$\mathrm{GF}^{\mathrm{A}}$} & \multicolumn{2}{c|}{$\mathrm{EN}^{\mathrm{A}}$} & \multicolumn{2}{c}{$\mathrm{RF}^{\mathrm{A}}$} \\
\cline { 2 - 7 } & $0 \mathrm{~W}-\mathrm{D}$ & 9 W-D & 0 W-D & 9 W-D & 0 W-D & 9 W-D \\
\hline$\theta_{\mathrm{S}}\left(\mathrm{m}^{3} \cdot \mathrm{m}^{-3}\right)$ & 0.335 & 0.369 & 0.443 & 0.433 & 0.512 & 0.507 \\
$\theta_{\mathrm{r}}\left(\mathrm{m}^{3} \cdot \mathrm{m}^{-3}\right)$ & 0.110 & 0.144 & 0.120 & 0.224 & 0.266 & 0.229 \\
$\alpha\left(\mathrm{m}^{-1}\right)$ & 0.538 & 0.538 & 0.183 & 0.152 & 0.178 & 0.143 \\
$\mathrm{n}$ & 1.425 & 1.580 & 1.123 & 1.234 & 1.361 & 1.224 \\
$\mathrm{~m}$ & 0.298 & 0.367 & 0.109 & 0.189 & 0.265 & 0.183 \\
$\mathrm{r}^{2}$ & 0.998 & 0.998 & 0.998 & 0.999 & 0.995 & 0.996 \\
\hline
\end{tabular}

${ }^{\mathrm{A}} \mathrm{GF}$, EN and RF represent Geric Ferralsol, Eutric Nitosol and Rhodic Ferralsol, respectively.

(1996) and Phogat and Aylmore (1989) showed changes in soil macroporosity distribution on wetting and subsequent drying processes. Their results indicated the instability of structural pores upon wetting and drying.

Recently, Pires et al. (2008) applied the log-normal Pore Size Distribution (PSD) model of matric potential to evaluate effects of W-D cycles on the structure of the same three soils used in the present study. These authors divided the soil pores into two categories: matrix or textural and structural pores, as suggested by Kutílek (2004). The obtained results showed that the application of successive W-D cycles caused important changes in the two categories of soil pores for all soils. For the GF and RF soils, the most important changes occurred in the structural domain (larger values of matric potential). On the other hand, for the EN soil, the most significant changes were found in the matrix domain. These results can help to explain the different changes in the SWRC (0 W-D and $9 \mathrm{~W}-\mathrm{D}$ ) obtained for the GF in relation to the other soils.

As the SWRC (Fig. 7) presented differences in the region of textural (pores diameter $<3.0 \mu \mathrm{m}$ ) and structural pores (pores diameter $>3.0 \mu \mathrm{m}$ ), a possible indication of these behaviors could also be the soil migrations of chemical elements. These element migrations will mainly affect the region of textural pores. It is well known that basic ions cause the flocculation of colloids, and the decalcification of soils causes dispersion and, in relation to the type of exchangeable bases, they affect clay expansion. The basal space among the layers of the clays can vary from $1 \mathrm{~nm}$, when occupied by $\mathrm{K}^{+}$, to
$1.5 \mathrm{~nm}$, when occupied by water molecules or hydrated $\mathrm{Ca}^{2+}$ and $\mathrm{Mg}^{2+}$ ions (Meurer 2006). It is also known that the soil development is influenced by a series of factors, such as: 1) exchangeable ions on the clay; 2) presence of iron and aluminum oxides that act as cementing agents; and 3) binding between organic and inorganic compounds (Kutílek and Nielsen 1994).

According to several authors, changes in $\mathrm{K}^{+}$and $\mathrm{Ca}^{2+}$ contents can affect the soil aggregate stability, which is directly related to water movement and retention (Camargo et al. 1983, Ravina 1973). Therefore, it is possible to conclude that changes in the soil chemical composition, after several W-D cycles, can probably affect the SWRC. This result has important consequences in agricultural applications because these modifications in the soil structure can affect plant and root development, as well as the evaluation of SWRC.

Another explanation for the changes in the SWRC due to W-D cycles can be attributed to soil volumetric modifications. These volume changes occur mainly for swelling soils that undergo significant bulk density variations according to their water content variation. However, this kind of phenomenon is more common for soils like Vertisols. In soils dominated by 2:1 clays (Vertisols), the aggregate stability is mainly affected by polyvalent metal-organic matter complexes that form bridges among the negatively charged clay platelets. In $1: 1$ clay-dominated soils, the stability is attributed to the binding capacity of the minerals themselves (Wakindiki and Ben-Hur 2002). Previous studies show that our studied soils are not composed by swelling 

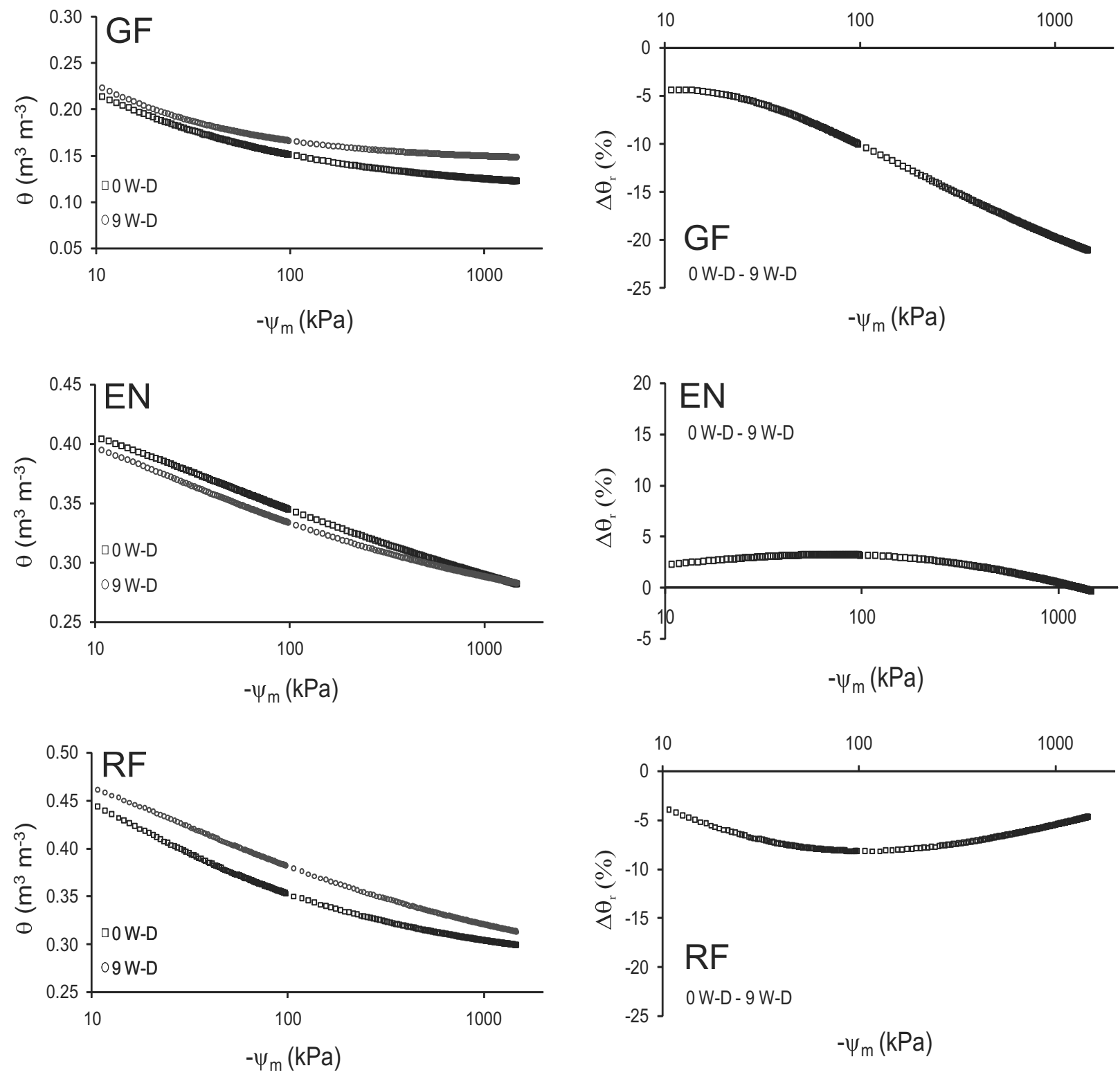

Fig. 6 - SWRCs obtained for treatments 0 W-D and 9 W-D cycles for GF, EN and RF soils.

Fig. 7 - Relative difference of soil volumetric water content $\left(\Delta \theta_{\mathrm{r}}\right)$ between the SWRC obtained for treatments $0 \mathrm{~W}-\mathrm{D}$ and $9 \mathrm{~W}-\mathrm{D}$ cycles for GF, EN and RF soils.

clays that present large content of smectite clay minerals. However, Pires et al. (2005) showed that the application of W-D cycles in samples collected in volumetric rings provokes changes in soil volume even for these non swelling-soils. According to these authors, this phenomenon occurs because, during wetting and after drying, the process of friction between the soil column and the cylinder wall can influence the adequate settlement of the sample. When the soil sample is submitted to several W-D cycles, this effect is increased

and changes in its height and, consequently, its volume, are observed. This change in soil volume directly affects the region of structural soil pores as observed for the GF and RF soils (Pires et al. 2009).

Another process that can affect the SWRC is the OM content. OM favors mainly the formation of stable soil structures and increase the water retention (Grohmann and Camargo 1973). The influence of OM in the microstructure of the soil can change the soil pore con- 
nectivity, which affects the water flow through pores. In our study, differences in the volumetric water content occurred in the following soil sequence: $\theta_{\mathrm{RF}}>\theta_{\mathrm{EN}}>$ $\theta_{\mathrm{GF}}$ (Table II and Fig. 6). This result was expected due to the higher OM content of the RF soil in relation to the EN and GF soils. Differences on saturated water contents $\left(\theta s_{\mathrm{RF}}>\theta s_{\mathrm{EN}}>\theta s_{\mathrm{GF}}\right)$ can also be explained by the soil compositions. It is known that clay soils (RF and $\mathrm{EN}$ ) present higher values of $\theta s$ than silt loam and sand soils (GF). Recently, Zhuang et al. (2008) studied the soil water hysteresis in water-stable microaggregates as affected by OM. These authors showed that OM removed by combustion reduced soil water retention in the microaggregates, and that the reduction tended to get smaller for lower matric potentials. This result suggests that more OM was present in larger pores instead of in smaller ones from which water was drained. Therefore, the OM distribution in soil structure can also explain some of the results obtained in this study (Figs. 6 and 7). For example, a high concentration of OM for a specific range in size of soil pores can help to explain the approximation of the SWRC before and after the application of W-D cycles. By using this hypothesis, we can conclude that the EN soil presents a more homogeneous distribution of OM for all classes of pore sizes after the application of W-D cycles (Fig. 7).

The process of hysteresis can also influence the SWRC. The main causes of hysteresis are air entrapment, variation in solid-liquid contact angle, different spatial connectivity of pores during wetting and drying process, and geometric non-uniformity of individual pores. In summary, hysteresis mainly occurs because of differences in pore shape, size and interconnectivity. In order to avoid the air entrapment, the very same procedure of soil saturation was always used during the application of W-D cycles in our study. This procedure was followed to avoid changes in soil structure during wetting (Klute 1986). A sudden immersion of samples in water can cause slaking of the soil aggregates and, consequently, changes in the SWRC. Unfortunately it was not possible to make the analysis of hysteresis in our study because the measurements of the wetting curve are both time and labor consuming, also requiring the use of expensive special equipments.

Chemical element migrations due to the application of W-D cycles are very important, once the respective ion losses can affect the quality of the SWRC and also of hydraulic conductivity measurements (Klute 1986). According to Lima et al. (1990), increases of sodium content in soils change the water holding capacity for a specific pressure as a result of pore-size reduction by swelling clay particles. As a consequence, the hydraulic conductivity can also be affected. Russo and Bresler (1977) also reported differences in the SWRC and hydraulic conductivities of soil samples saturated with solutions containing a given composition of $\mathrm{Na}^{+}$and $\mathrm{Ca}^{2+}$ ions. These last authors demonstrated that an increase in the $\mathrm{Na}^{+}$to $\mathrm{Ca}^{2+}$ ratio and a decrease in the soil solution concentration greatly affect soil water-suction relationships. Oliveira et al. (2005) assessed the influence of W-D cycles on Water-Dispersible Clay (WDC) and showed that soils of reduced aggregate stability are more susceptible to the action of W-D on the WDC. According to Frenkel et al. (1978), the plugging of pores by dispersed clay particles is the major cause of reduction in hydraulic conductivity and changes in suction head when the ion concentrations of soils are changed.

\section{CONCLUDING REMARKS}

The investigation of the migration of chemical elements of the soil by AAS led to the quantification of some ion losses when a soil is submitted to several W-D cycles. The analysis of EC indicates that the application of up to nine W-D cycles produced significant losses of ions for the three Brazilian tropical soils (GF, EN and RF) investigated in this study. It was also observed by the AAS technique that the ions $\mathrm{Ca}^{2+}, \mathrm{Mg}^{2+}$ and $\mathrm{K}^{+}$presented significant decreases in the soils after repeated $\mathrm{W}-\mathrm{D}$ cycles. The result was in part associated with the lyotropic series that defines the strength of bonding between ions and clay surfaces. The soil water retention curves presented differences in the region of both textural and structural pores after the application of W-D cycles. These differences are probably associated with changes in soil structure and in soil chemical composition after sequences of wetting and drying.

\section{ACKNOWLEDGMENTS}

The authors are grateful to Conselho Nacional de Desenvolvimento Científico e Tecnológico (CNPq) and Coordenação de Aperfeiçoamento de Pessoal de Nível 
Superior (CAPES) (Grant no. BEX1245/05-8) both of Brazil, for the financial support and fellowships.

\section{RESUMO}

Os ciclos de umedecimento e secamento (U-S) podem induzir importantes migrações de elementos químicos no solo. $\mathrm{O}$ objetivo principal deste trabalho foi estudar a possível existência de migração de elementos químicos em amostras de solos submetidas a repetidos ciclos de U-S durante a avaliação da curva de retenção de água do solo. As determinações de $\mathrm{Ca}^{2+}$, $\mathrm{Mg}^{2+} \mathrm{e} \mathrm{K}^{+}$foram obtidas por Espectrometria de Absorção Atômica em três diferentes solos tropicais do Brasil (Latossolo Vermelho-Amarelo, Nitossolo Vermelho e Latossolo Vermelho). Os resultados demonstram um aumento da condutividade elétrica da água extraída das amostras de solo e perda significativa de $\mathrm{Ca}^{2+}, \mathrm{Mg}^{2+} \mathrm{e} \mathrm{K}^{+}$após a aplicação de nove ciclos de U-S. Diferenças nas curvas de retenção foram também observadas para todos os solos quando as amostras submetidas aos ciclos de U-S foram comparadas com as amostras não submetidas. Essas diferenças ocorreram tanto na região estrutural quanto textural dos poros do solo. Uma possível explicação para esses resultados pode ser a migração de elementos químicos do solo durante as sequências de ciclos de U-S, os quais podem afetar o desenvolvimento da estrutura do solo.

Palavras-chave: métodos analíticos, estrutura do solo, ciclos de umedecimento e de secamento, física do solo.

\section{REFERENCES}

Camargo lC, Moniz aC, Jorge JA and Valadares JMAS. 1986. Métodos de análise química, mineralógica e física de solos. Boletim Técnico, 106. Campinas: Instituto Agronômico de Campinas (IAC), 94 p.

CAMARgo OA, Valadares JMAS ANd Geraldi RN. 1983. Características químicas e físicas de solo que recebeu vinhaça por longo tempo. Boletim Técnico, 76. Campinas: Instituto Agronômico de Campinas (IAC), $30 \mathrm{p}$.

FAO. 1998. World reference base for soil resources. World Soil Resources Report 84. Rome: Food and Agriculture Organization of the United Nations, 91 p.

Frenkel H, Goertzen JO and Rhoades JD. 1978. Effects of clay type and content, exchangeable sodium percentage, and electrolyte concentration on clay dispersion and soil hydraulic conductivity. Soil Sci Soc Am J 42: 32-39.
GROHMANn F AND CAMARGO OA. 1973. Influência dos óxidos de ferro livres e da matéria orgânica na adsorção de água pelo solo. Bragantia 32: 203-222.

Havlin JL, Beaton JD, Tisdale SL and Nelson WL. 2005. Soil fertility and nutrient management: an introduction to nutrient management. New Jersey: Prentice Hall, 515 p.

KLUTE A. 1986. Water retention: laboratory methods. In: BLACK CA (Ed), Methods of Soil Analysis. I. Physical and Mineralogical Methods, Madison: ASA, Madison, USA, p. 635-662.

KUTíLEK M. 2004. Soil hydraulic properties as related to soil structure. Soil Till Res 79: 175-184.

Kutílek M And Nielsen DR. 1994. Soil Hydrology. Germany: Catena Verlag, $370 \mathrm{p}$.

Lima LA, GRISMER ME AND Nielsen DR. 1990. Salinity effects on Yolo Loam hydraulic-properties. Soil Sci 150: 451-458.

Meurer EJ. 2006. Fundamentos de química do solo. Porto Alegre: Evangraf, 285 p.

Nimmo JR. 1997. Modeling structural influences on soil water retention. Soil Sci Soc Am J 61: 712-719.

Oliveira TS, Costa LM AND Schaefer CE. 2005. Water-dispersible clay after wetting and drying cycles in four Brazilian oxisols. Soil Till Res 83: 260-269.

Phogat VK AND AYLMore LAG. 1989. Evaluation of soil structure by using computer-assisted tomography. Aust J Soil Res 27: 313-323.

Pires LF, BACCHI OOS AND REICHARDT K. 2005. Gamma ray computed tomography to evaluate wetting/ drying soil structure changes. Nucl Instr Meth Phys Res B 229: 443-456.

Pires lF, Cassaro FAM, Reichardt K and Bacchi OOS. 2008. Soil porous system changes quantified by analyzing soil water retention curve modifications. Soil Till Res 100: 72-77.

Pires LF, Reichardt K, Cooper M, Cassaro FAM, DiAS NMP AND BACCHI OOS. 2009. Pore system changes of damaged Brazilian oxisols and nitosols induced by wet-dry cycles as seen in 2-D micromorphologic image analysis. An Acad Bras Cienc 81: 151-161.

RAVINA I. 1973. The mechanical and physical behavior of Ca-clay soil and K-clay soil. In: HADAS A (Ed), Physical aspects of soil water and salts in ecosystems, Berlin: Springer-Verlag, Berlin, Germany, p. 131-140.

Reeve MJ, Smith PD and Thomasson AJ. 1973. The effect of density on water retention properties of field soils. J Soil Sci 24: 355-367. 
RICHARDS LA. 1941. A pressure-membrane extraction apparatus for soil solution. Soil Sci 51: 377-386.

Russo D AND BRESLER E. 1977. Effect of mixed Na-Ca solutions on hydraulic-properties of unsaturated soils. Soil Sci Soc Am J 41: 713-717.

SAlter PJ AND Williams JB. 1965. The influence of texture on the moisture characteristics of soils. II. Available water capacity and moisture release characteristics. J Soil Sci 16: 310-317.

SARMAH AK, PILlai-McGarry UUP AND MCGARRY D. 1996. Repair of the structure of a compacted Vertisol via wet/dry cycles. Soil Till Res 38: 17-33.

SPARKS DL. 1998. Soil Physical Chemistry, $2^{\text {nd }}$ ed., London: Lewis Publishers, $409 \mathrm{p}$.

VAN GENUChTEN MTh, LiEJ FJ AND YATES SR. 1991. The RETC code for quantifying the hydraulic functions of unsaturated soils. Riverside: USDA.

VAN RAIJ B. 1969. A capacidade de troca de cátions das frações orgânica e mineral em solos. Bragantia 28: 85112.
VAN RAIJ B. 1986. Propriedades eletroquímicas de solo. In: Simpósio AVANÇAdo DE QuímicA E FERTILIDADE Do Solo, Piracicaba. Anais..., Campinas: Fundação Cargill, p. 9-41.

VAN RAiJ B And Kupper A. 1966. Capacidade de troca de catíons em solos: estudo comparativo de alguns métodos. Bragantia 25: 327-336.

VAN Raij B, Quaggio JA, Cantarella H, Ferrerira ME, Lopes AS AND BATAglia OC. 1987. Análise química do solo para fins de fertilidade. Campinas: Fundação Cargill, $170 \mathrm{p}$.

WAKINDIKI IIC AND BEN-HuR M. 2002. Soil Mineralogy and texture effects on crust micromorphology, infiltration, and erosion. Soil Sci Soc Am J 66: 897-905.

Zhuang J, McCarthy JF, Perfect E, Mayer LM And JASTROW JD. 2008. Soil Water Hysteresis in WaterStable Microaggregates as Affected by Organic Matter. Soil Sci Soc Am J 72: 212-220. 